\title{
Corporate Image and its Impact on Consumer Decision Making in Slovakia
}

\author{
Vartiak Lukas ${ }^{1}$, Gogolova Martina ${ }^{2}$ and Majerova Jana ${ }^{3}$ \\ ${ }^{1}$ Comenius University, Faculty of SAES, Institute of Mediamatics, Mlynske luhy 4, 82105 Bratislava, \\ Slovak Republic \\ ${ }^{2}$ University of Zilina, Faculty of PEDAS, Department of Economics, Univerzitna 8215/1, 01026 Zilina, \\ Slovak Republic \\ ${ }^{3}$ AMBIS University, Department of Economics and Management, Lindnerova 575/1, 18000 Prague, \\ Czech Republic
}

Correspondence should be addressed to: Vartiak Lukas; lukas.vartiak@fses.uniba.sk

Received date: 30 June 2021; Accepted date:20 October 2021; Published date: 27 January 2022

Academic Editor: Katarzyna Chłapek

Copyright (C) 2022. Vartiak Lukas, Gogolova Martina and Majerova Jana. Distributed under Creative Commons Attribution 4.0 International CC-BY 4.0

\begin{abstract}
The primary aim of the paper is to empirically determine how presented experiences of other customers affect the creation and perception of the corporate image. Corporate image perceived by consumers can also be formed solely on the basis of sharing experiences of other consumers. Thus, there is a relationship between the polarity of presented experience (negative / positive) and the polarity of perceived corporate image. Negative experiences have more significant impact on the creation of a negative image than positive experiences have on a positive image. At the same time, the corporate image is in a relationship with the probability of buying and consumer product quality expectations. Positive image, however, can only dull acceptance of higher prices. Priming effect was not seen.
\end{abstract}

Keywords: Consumer, Corporate image, Priming effect.

\section{Introduction}

One of the aspects that the era of globalization brings is an increasingly differentiated market to the supply side (goods and services). There is a wide range of products available for the consumers. Customers can specify their requirements in more detail and they can also choose from various combinations of the product features. With the advent and development of information technologies, which provide

Cite this Article as: Vartiak Lukas, Gogolova Martina and Majerova Jana (2022)," Corporate Image and its Impact on Consumer Decision Making in Slovakia", IBIMA Business Review, Vol. 2022 (2022), Article ID 340734, DOI: $10.5171 / 2022.340734$ 
an easy access to information, consumers can share their experience related to the product. At the same time, experience of other consumers (groups or individuals) is available for consumers as well.

Also, the marketing aim of companies is to focus their activities in order to influence the broader part of their segments, not only by advertising but more often through marketing on social networks and content marketing. Companies are more focused on building positive relationships with existing and potential customers, they sell product with a sense of belonging to the group. They intend to determine how customers, suppliers, nearby and distant surroundings feel about them and look at them and how they can influence this picture in mind. Companies are aware that the corporate image can have both positive and negative effect on their business goals, and not only on business goals as such.

The following studies discuss the broad exposure of the corporate image - from the adoption of better marketing efforts of companies (Karaosmanoglu et al., 2011; Rentkova, Vartiak, 2017), through interest in working for a company (Tsai et al., 2010) and (Lemmink et al., 2003), loyalty to the company (Kaur et al., 2013; Nguyen et al., 2001; Bielikova, 2008), up to the perceptions of related quality of products (Minkiewicz, 2011; Krizanova \& Stefanikova, 2012; Billett et al., 2014; Lara et al., 2017).

The theoretical part of the paper focuses on the definitions of the terms corporate image, consumer decision making and behavioral economics.

In the empirical part, we will attempt to find out how experience with products and companies and the perception of a company influence the corporate image making process. An attempt will be made to determine the effect of positive and negative experiences of other consumers on the creation of the corporate image. At the same time, we will try to identify whether the perceived image affects customers' willingness to purchase a product and what impact it will have on the price that consumers are willing to pay for a product (Lehutova \& Gregova, 2012, Jankalova, Vartiak, 2016, Hampl, 2017, Vayrakh $\mathrm{Yu}, 2021)$.

The primary aim of the paper is to empirically determine how the presented experience of other customers affects the creation and perception of the corporate image. The secondary aim is to examine whether and how the relationship is demonstrated between the consumer subjectively perceiving corporate image and other selected factors (e.g., desire to buy a product, the level of the price they are willing to buy and the quality of products derived from the corporate image).

\section{Literature Review}

Corporate image is a subjective projection of an individual which depends not only on the cognitive assessment, but to a great extent, on the processing of emotional context and imperfections of human thinking. Despite the fact that economic theories base their assumptions on rational agents, many studies in Behavioral economics suggest rather predictable irrationality or significant limitations in human information processing and in the decision - making processes. Irrationality affects the decision-making process of the consumer when buying (Mandler, 2014). It is confronted with an existing corporate image mediated by other consumers and at the same time it also creates its own corporate image.

Image (the picture) is an integral part of every company which interacts with other market players. In marketing, the concept of image began to develop in the fifties of the 19th century. For the first time, it was described by B.B. Gardner and S.J. Levy (1955), and it was used with the number of the objects. Gardner and Levy identified three main types of image:

- Corporate image - the way of perceiving the company as a whole.

- Product image - the way of perceiving a particular product or product category (product line, product range). 
- Brand image - the way of perceiving a single brand by the customers, based on their interactions.

There is an assumption that the consumer does not realize the differences between the images. At the same time, the images may overlap and interchange on the consumer market. For the consumers themselves, it is important to perceive and personalize the images. It is also vital to have the ability to separate company/brand/product while these factors influence each other.

The creation of the image is the result of the communicative process and is most often associated with the recipient of information (Dukerich et al., 1998). Langerova (1957) defines projection on the side of the recipient as follows: "more or less stable form of registration of subjective sensory experience that is not a direct copy of a real experience but was reflected in the process of copying to a new dimension." Atvesson (1990) adds that it is "false or simplified representation of true or deeper reality." The creation of the image (picture) belongs to the simplification of human experience. It has developed as a result of the lack of interaction and knowledge about the object. When there is a frequent and deep interaction with objects, the previously created image will become unsustainable and outdated (ThØger Christensen et al., 2001; Hassan, Shamsudin, Mustapha arciaSalirrosas, 2019; Gordillo, 2021).

One of the most commonly used definitions of corporate image was coined by Kennedy (1977). He defines it as "an overall impression given by the organization (company) generated in the different groups. This is dependent on various factors and physical behavior of the organization (company), such as company name, product diversity, traditions, ideologies and feel the quality of communications between clients." Similarly, Dichter (1985) states that "image does not describe specific characteristics or quality, but the overall impression company leaves in the minds of others." Margulies (1977) defines the corporate image as its identity (all the ways that a company chooses to identify itself), while he further describes that "corporate image is the perception of the identity of the organization (company) public, communities, customers, employees, the press, current and potential stockholders, security analysts and investment bankers." With the development of psychology, the definitions of concepts such as emotion and belief are emerging. According to Kotler and Barich (1991), "the image represents all assumptions, opinions and impressions that a person has against the company. These impressions may be true, false, real or imaginary. Corporate image describes the public view of corporate goodwill, company, employees, customers and other stakeholders (the general perception in the mind of consumers)."

Marketing corporate image is "the way people view the quality of the company through marketing offers and marketing mix and treat a value exchange offering companies compared to the competition." Also, the attention is paid to the fact that the company produces more image (projections) at the same time, which may vary according to the specific recipients of information (different types of stakeholders and shareholders), because each individual and group comes into interaction with a company in a different situation and takes away the unique experience (Dowling, 1986; Dowling, 1988; Barich et al., 1991). The image is determined by a number of factors, including the typical stereotypes of users or the general brand users (Siregy et al., 1985; Aaker, 1997). To put it in a simple way, each customer can perceive and describe a company in a different way, depending on the personal or shared experiences and information.

Corporate image as a whole can be described as an "urgent mental image of the company based on the feelings and opinions of individuals." (Brown, 2006, Loock, Phillips, 2020) and as a "perception of the organization within its environment" (Thøger Christensen et al., 2001). 
The image affects multiple parts of the personality of the consumer; thus, it can be described as a multi-component concept (Bartova et al., 2002):

- Cognitive - the knowledge about the product and intellectual processing.

- Affective - emotional elements associated with the brand.

- Conative - tendency towards certain type of behaviour, purchase, use.

According to Vysekalova and Mikes (2009), "the image has the character of a generalized and simplified symbol based on the summary of ideas, attitudes, beliefs, and experiences of a person about a certain object."

At present, in a complex world associated with the information overload and with information resources, the creation of the image (pictures, ideas) is a way to grasp reality, to simplify it and make it acceptable, which subsequently affects our subsequent decision - making process. When processing, we often make cognitive errors (biases) and heuristics that have an impact on the outcome of the cognitive process of creating the image.

The emergence of the image is the result of a complex psychological process in which expectations and associations play a significant role. Similarly to Pavlov's experiment with dogs, the sense perception (in the form of a brand name company or of a product or the stimulus intrinsically linked to a company) may evoke the image stored in the memory and the feelings associated with it, depending on the intensity of the consumer associations.

According to Meffert (2005) and Herbst (2009), the creation of the corporate image depends on the following elements:

- merit expectations of the company (what is obtained for the money that is spent),

- expectations of the particular characteristics of the company (the company whose features are considered important),

- general expectations of the company (how business should be conducted in the context of general and moral requirements of the company),

- level of abstraction associations,

- associations strength (how hard the image is tied up to specific emotions, behavior, etc., how strong the reaction to a stimulus is),

- uniqueness of associations (what makes the company unique),

- promises of advantages (what positive reward is coupled with my idea).

At the same time, a significant factor cannot be neglected - the interaction of existing image among individuals and groups. Thus, not only the company itself but also entities in the area, such as other customers, have an impact on the creation of the corporate image (Karaosmanoglu et al., 2011; Kaur, Soch, 2018; Ponisciakova, Kicova, 2021).

\section{Methodology and Data}

At present, many people search for information on the Internet in order to make a decision to purchase a particular product. People use various forms of social networking, evaluation review site, they also ask their friends. All these forms can be regarded as a certain type of WORD OF MOUTH (Majerova, 2014).

In terms of the typology of decision making, respondents were invited to decide on the basis of available information. However, in reality, it is possible that the amount of the information obtained will not be higher. Therefore, we tried to find out how these representations influence the formation of the image. In an attempt to find out how these representations influence the formation of the image and in order to obtain answers to our questions, the form of a questionnaire survey was used.

The survey focused on respondents who are residents of the Slovak Republic at the age ranging from 18 to 39 years. These respondents were chosen because of their experience with working with the Internet sources. The age delimitation was also employed with the aim of a better statistical validity and expected lower

Vartiak Lukas, Gogolova Martina and Majerova Jana, IBIMA Business Review,

DOI: $10.5171 / 2022.340734$ 
return rate (i.e., participation). We decided to conduct our research via the Internet because of the possible large territorial range and the diversity of the available selection of respondents.

The questionnaire was distributed through the Internet. We created a web page where a respondent randomly chose one of the variants. This allowed ensuring that the respondent did not know which questionnaire would be available for him/her. The actual questionnaire was administered in Google sheets which ensured automated data processing. The questionnaire was available from November 20, 2020 to June 1, 2021. The survey covered a total of 157 respondents, however, in the process of evaluation, we included only 149 respondents who met the required standards. As some versions were filled in by a smaller number of respondents, this resulted into a higher degree of statistical dispersion, which is noted in the graph of individual results.

As we intended to obtain the information on the relationship of expression - image, five representations of virtual clients were created. Each consisted of 10 representations and the options mutually differed in the composition of representations. The variants were presented in a similar form which can be encountered on social networks, and we used the photo with the face in order to highlight the credibility.
We did not use a reference to existing companies with which the respondent could have already established relationship and the image that would be difficult to change. Consequently, we could encounter more cognitive errors in perception (confirmation bias, selective perception). At the same time, we intended to test the effect of one of the cognitive errors PRIMING.

PRIMING - is a mechanism described in cognitive psychology as a mechanism that affects the behavior with initial information and its associations. The bestknown experiment with priming was an experiment in which a group of young students were supposed to create sentences related to the context of the old age. Afterwards, they were sent for rewards which were located about a kilometer away and the time in which they passed this distance was measured. This group was statistically significantly slower in the time shift compared to control groups that were primed to youth or that were without priming.

In our research, we intended to test the socalled contextual priming where we focused on past scientific studies dealing with the color context and the meaning of the word.

\section{Results and Discussion}

As stated in the Methodology and data, in the case of the version with 10 negative opinions, the results did not differ from our assumptions (Fig. 1). 


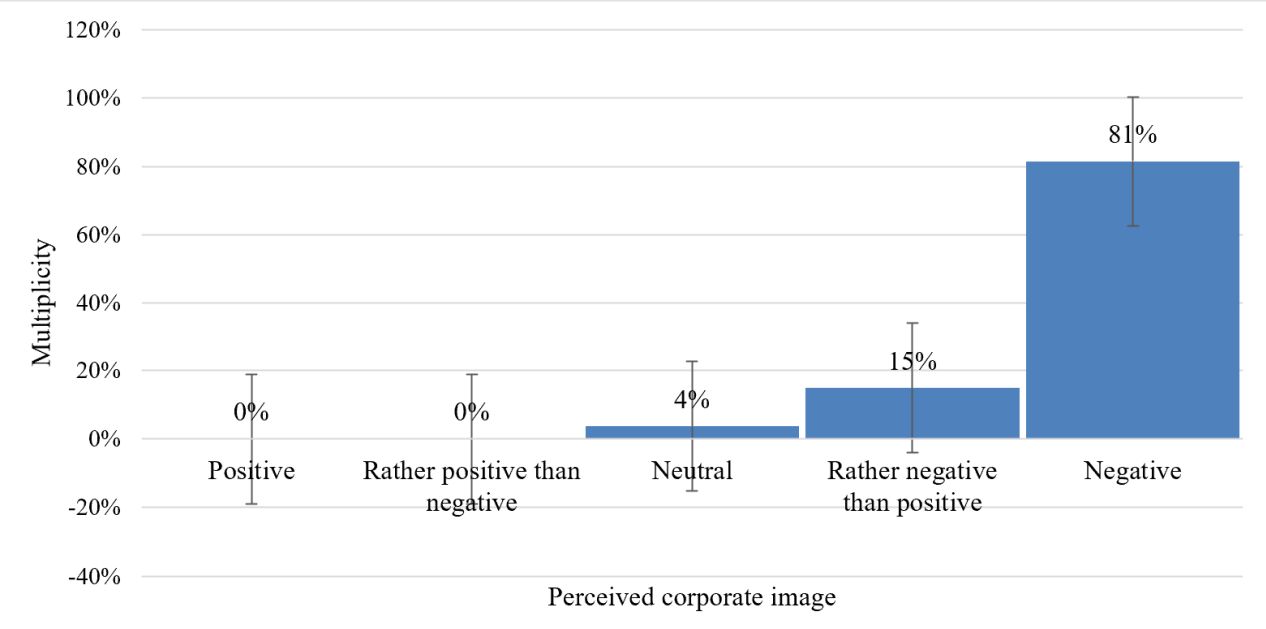

Fig 1. Perceived corporate image based on 10 negative opinions

In the case of the version with 10 positive opinions, it can be seen that differentiation is concentrated between three opinions and is not that clear (Fig. 2).

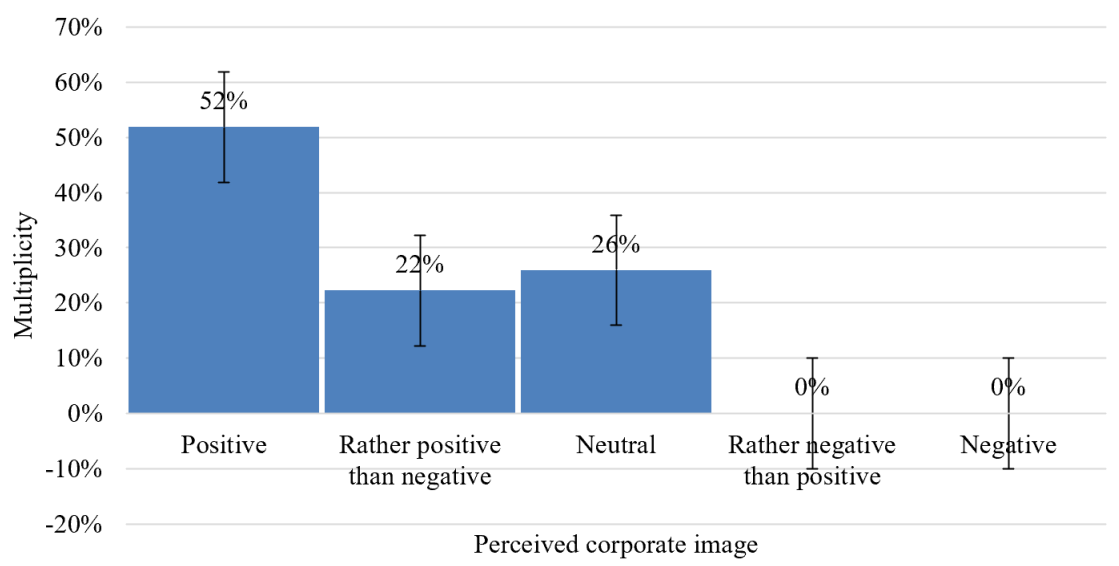

Fig 2. Perceived corporate image based on 10 positive opinions

In the case of the version with 5 positive and 5 negative opinions, it can be observed that the division is shifted to the right negative side. The expected division of image dominated in the neutral rating.
However, upon closer investigation, it was found that the overall perception of image was not affected by the composition of opinions but by the importance of the preferred opinions (Fig. 3). 


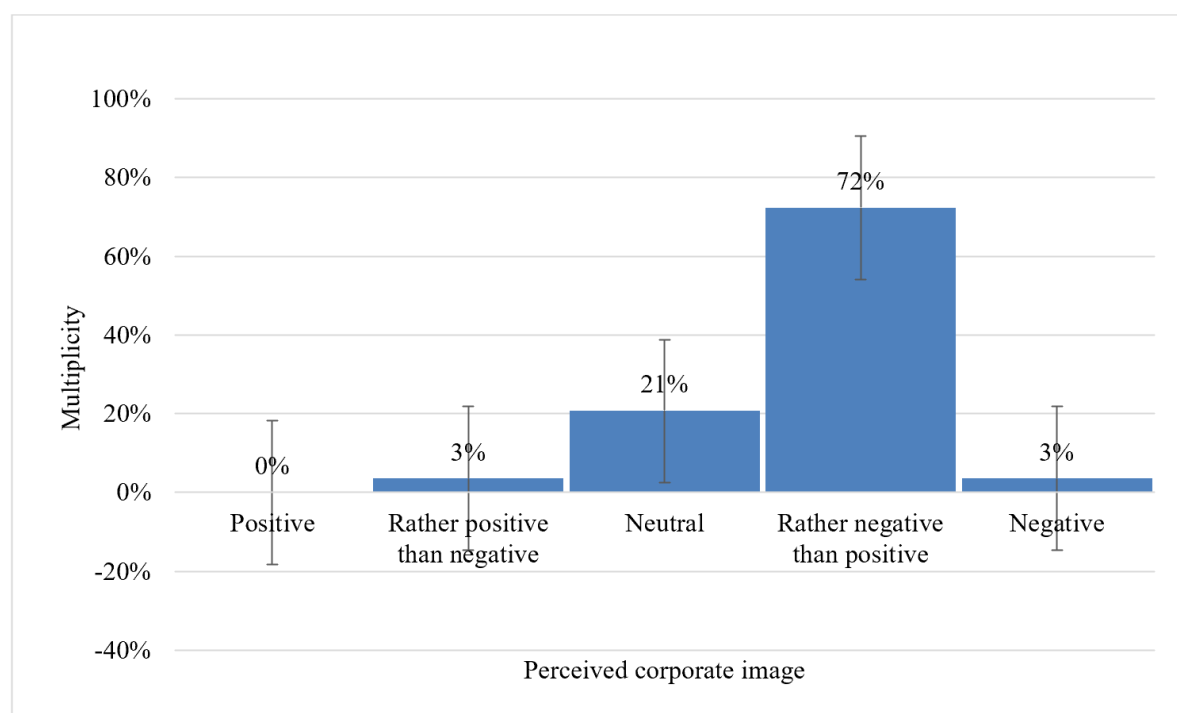

Fig 3. Perceived corporate image based on 5 positive and 5 negative opinions

According to versions with positive and negative priming, the expected effect was not confirmed (Positive priming - Fig. 4, Negative priming - Fig. 5).

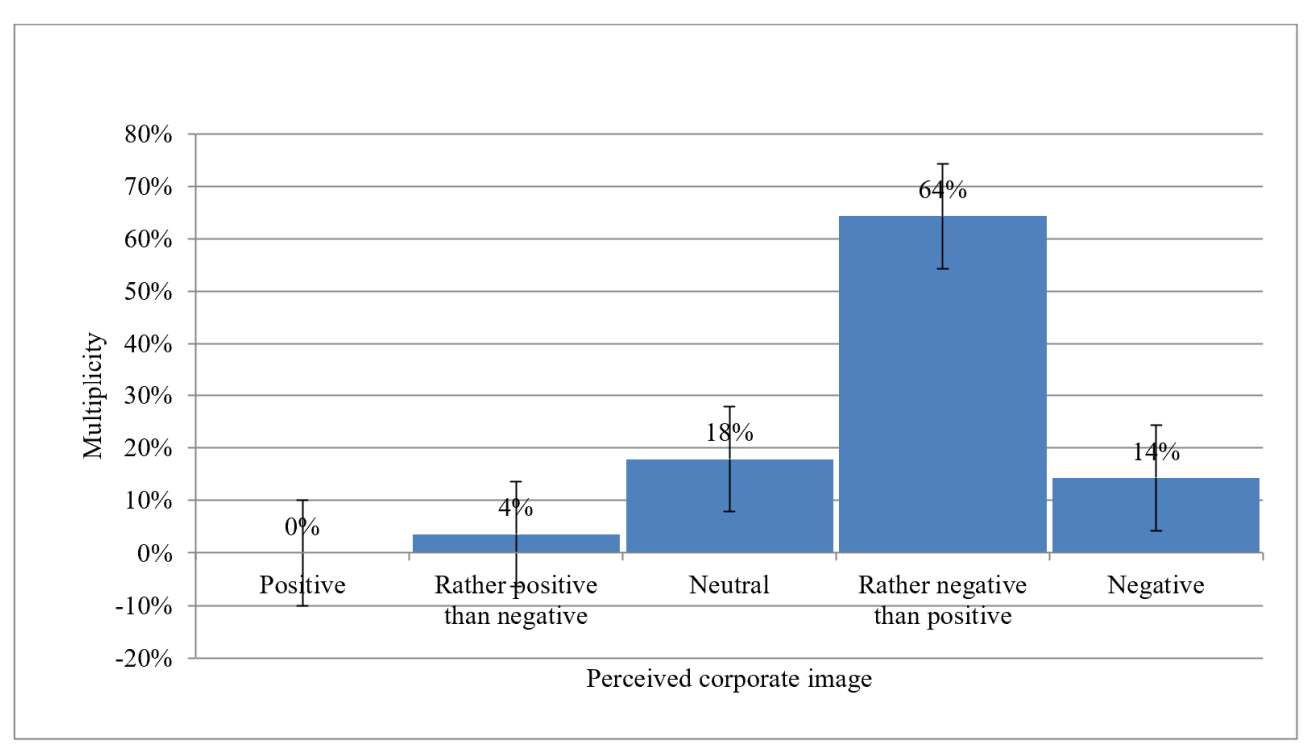

Fig 4. Perceived corporate image - positive priming

Vartiak Lukas, Gogolova Martina and Majerova Jana, IBIMA Business Review, 


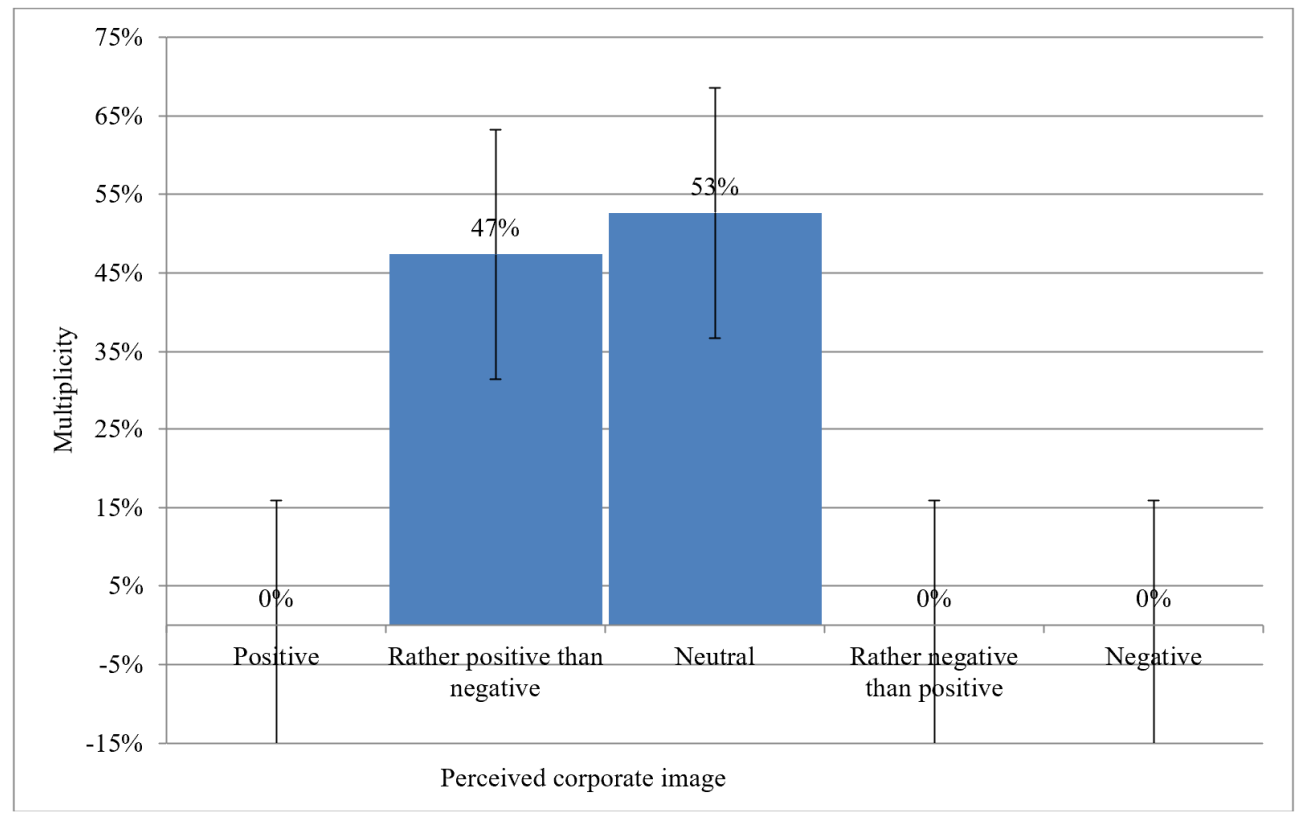

Fig 5. Perceived corporate image - negative priming

Again, on the basis of the answers of respondents, preferred polarity affects opinions on the overall perception of the image.

Thus, we decided to verify the relationship between the polarity and the perceived image. The expected relationship was confirmed by the contingency in both graphic and numerical form. We can also observe different layouts of the perceived image and confirmation of the assumption that a negative expression is more important in the process of creating the image than a positive expression (Fig. 6 and Fig. 7).

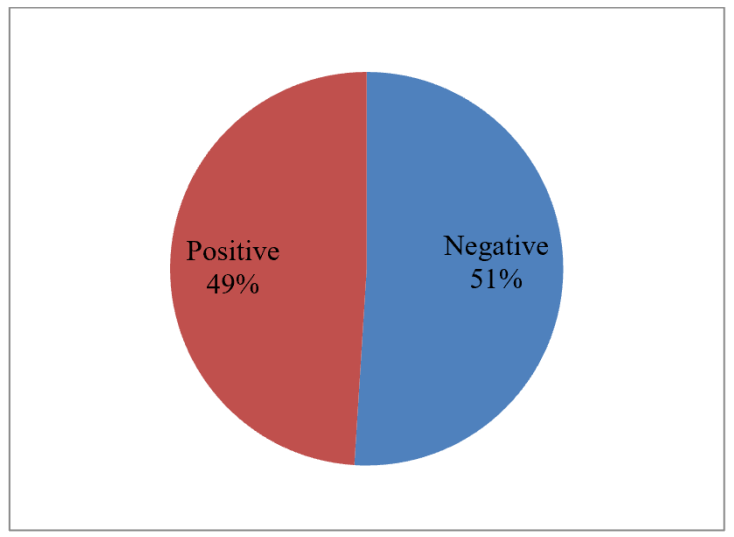

Contingency intensity

The Pearson coefficient

$\mathbf{C}=\mathbf{0 , 6 4 1 8}(0,3 ; 0,8>-$ moderate (middle)

dependence

The Cramer coefficient

$\mathrm{K}=\mathbf{0 , 8 3 6 9}$

$(0,7 ; 1>-$ strong dependence

Fig 6. The division of the preferred attributes provided by respondents 


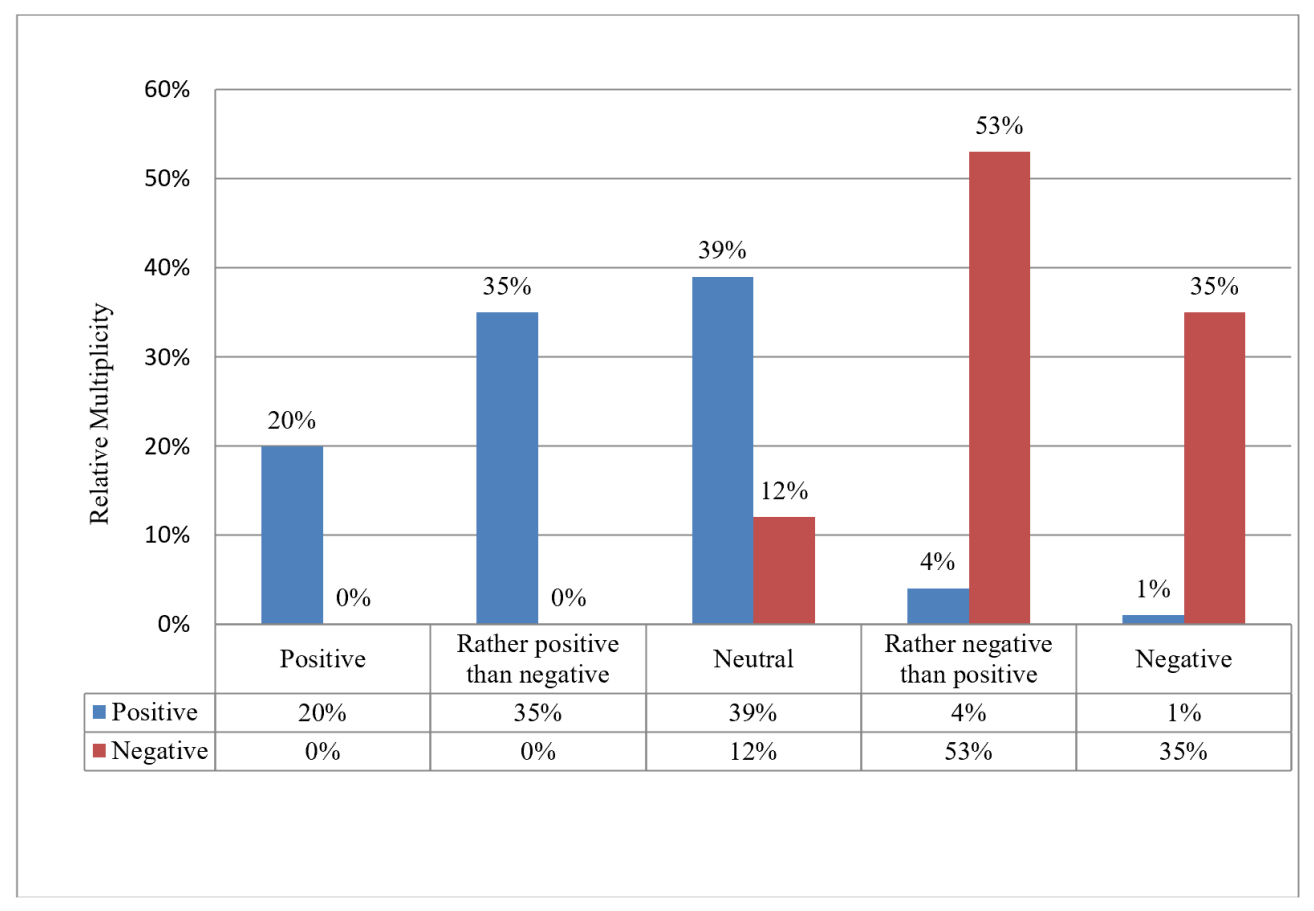

Fig 7. Perceived image depending on the polarity of preference

In the next section, we investigated the relationship between perceived image and:

- the willingness to purchase the product,

- the willingness to pay a price level compared to the average market price,

- the perception of derived product quality.

The relationship between the perceived corporate image and the willingness to buy a product of the company was confirmed by mathematical contingency with the moderate and strong dependence. Therefore, positively perceived corporate image can bring a greater willingness to purchase the product, and negatively perceived corporate image can contribute to the reluctance to purchase the product. Even neutral corporate image may result into a greater willingness to purchase the product (Fig. 8). 


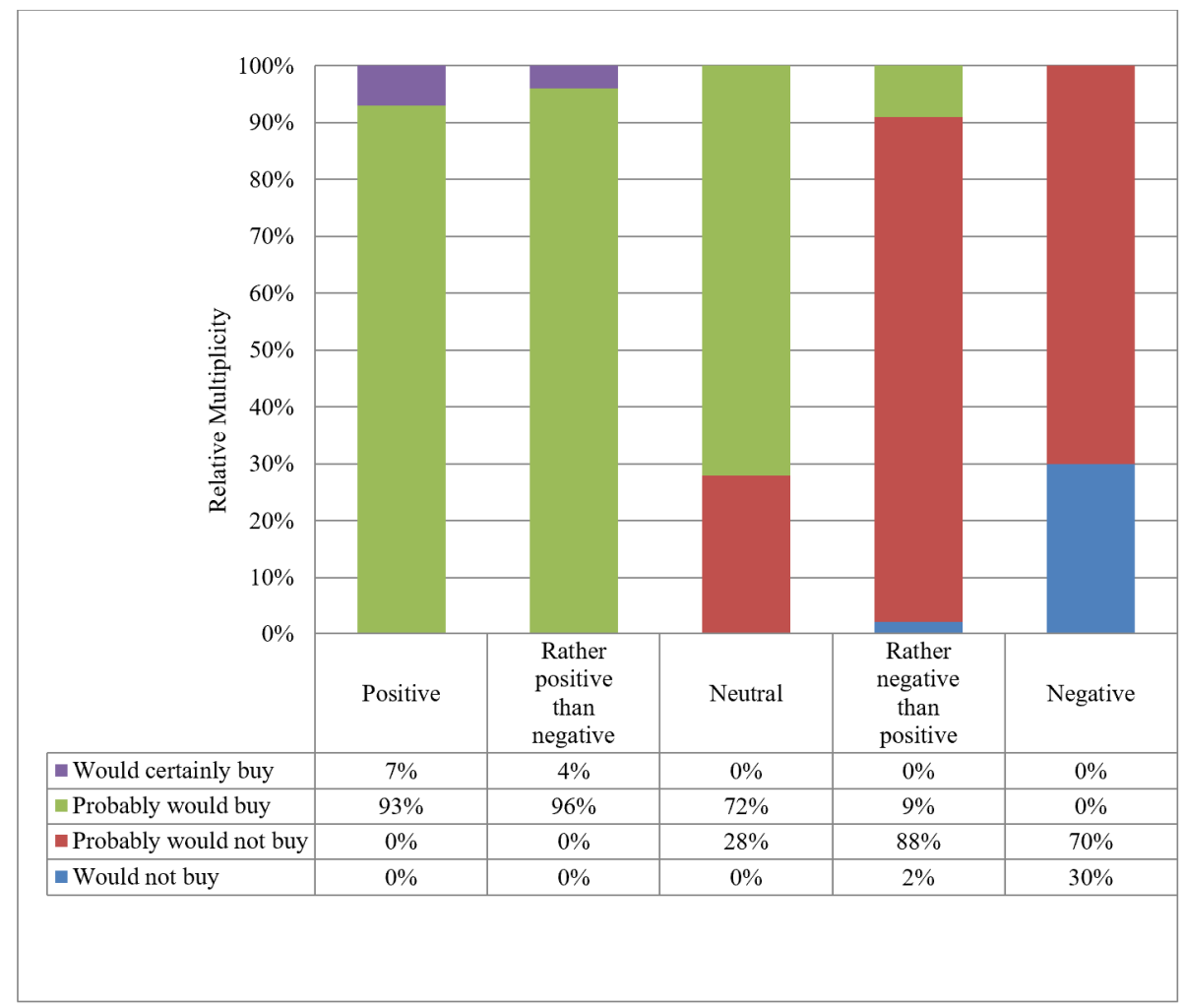

Contingency intensity

The Pearson coefficient $\mathbf{C}=\mathbf{0 , 6 3 9 0}(0,3 ; 0,8>-$ moderate (middle) dependence

The Cramer coefficient $\mathbf{K}=\mathbf{0 , 8 3 0 8}(0,7 ; 1>-$ strong dependence

Fig 8. The relationship between the perceived corporate image and the willingness to buy a product of the company

The relationship between the perceived corporate image and the accepted price was also confirmed by mathematical contingency but only with low dependence. A better image will therefore bring significant willingness to pay extra money for a product (Fig. 9).

Vartiak Lukas, Gogolova Martina and Majerova Jana, IBIMA Business Review, 


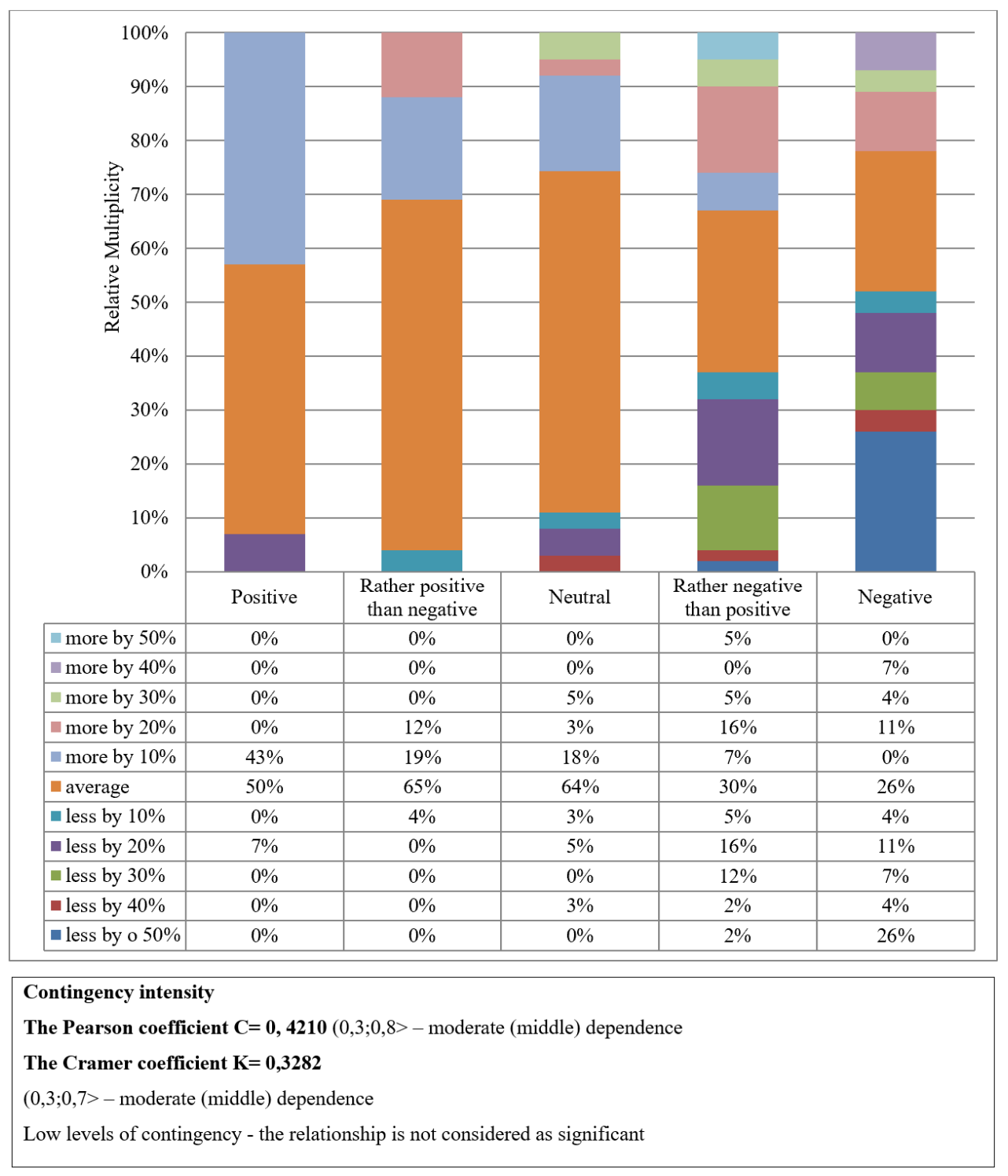

Fig 9. The relationship between the perceived corporate image and the accepted price

In the last section, the relationship between the perceived corporate image and the derived product quality was confirmed by graphic results and by mathematical results as well. There is a moderate contingency rate so there is a middle dependence. The option not being able to evaluate was excluded (Fig. 10). 


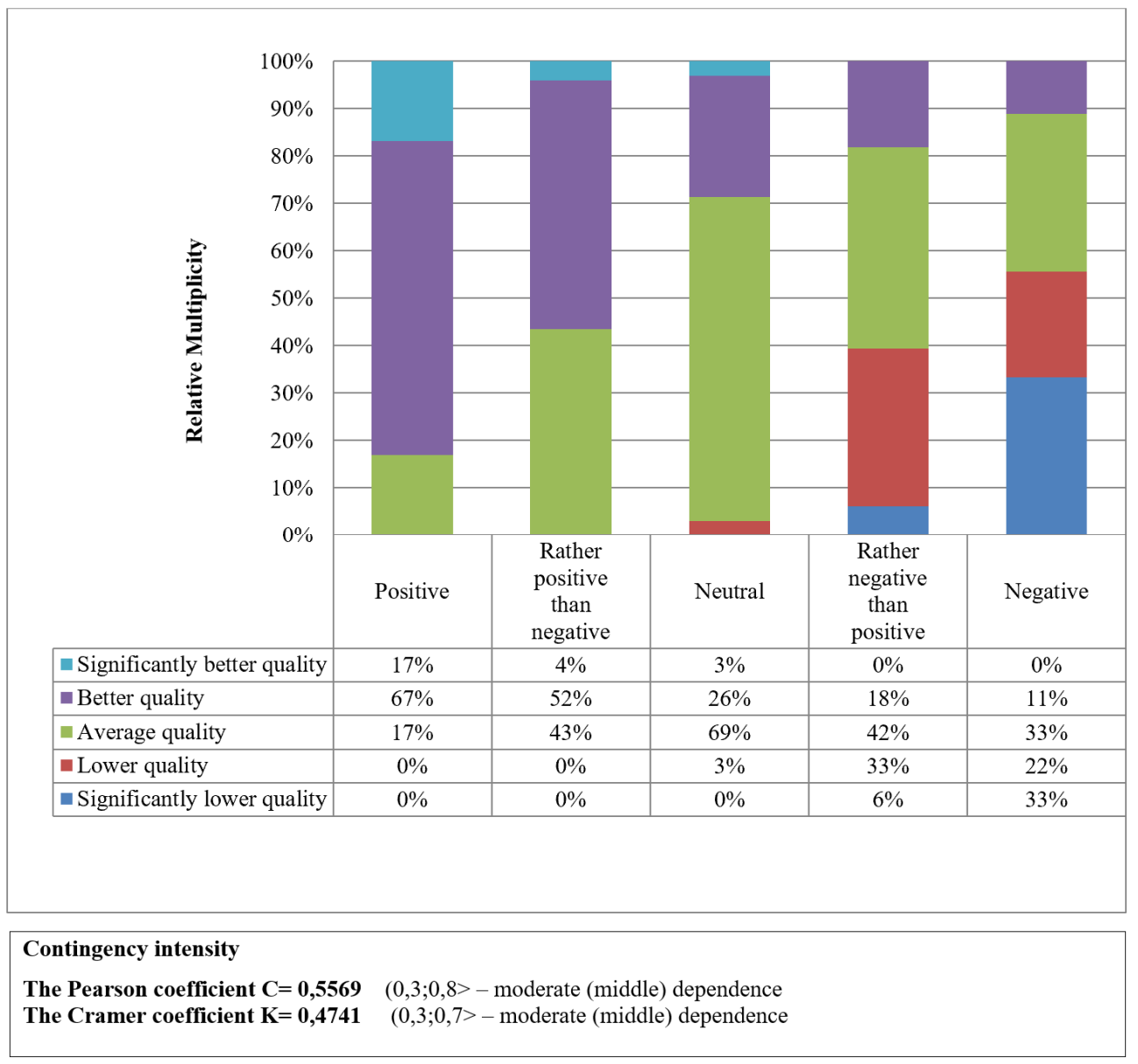

Fig 10. The relationship between the perceived corporate image and derived product quality

\section{Conclusion}

The results indicate that there is an existing relationship between the structure of virtual customers' opinions and the creation of the image. The results suggest a greater impact of negative customer opinions to create a negative image than positive comments on the creation of a positive image. It was not possible to confirm the priming effect.

Between mid - derived contingency intensity and the level of the price range, there is a moderate level of contingency at the lower end. Thus, there is not a strong relationship.

The obtained information can be evaluated in the following way: the corporate image and company's effort to control it is important for the company. Not only personal experience but also a secondary flow of information about the company in the form of sharing of experience (word of mouth) influence the formation of the corporate image. Consumer was able to create the corporate image on the basis of the presented experience of other consumers. Exclusively, negative 
experience of fictitious consumers created a negative image among respondents and it is only positive experience that creates a positive image. It was also found out that mediated negative experience with the company was more significant for creating a negative image than a positive experience on the creation of a positive image.

In the case of different relative proportion of positive and negative opinions, it was found out that among survey respondents from 18 to 39 years of age, it was the sole opinion favoured by respondents that influenced the creation of the image and its negative, or positive polarity, respectively. At the same time, we were not able to present the impact of contextual priming for the creation of the corporate image.

We were able to demonstrate the impact of a positive image on consumers' purchasing decision-making process which brought a significant willingness to purchase the product. Equally negative image had a negative impact on the willingness to purchase the product. Positive or negative image cannot create a decisive opinion of respondents with regards to their purchase.

The corporate image as such had a less significant impact on the acceptable price for the product. While a positive image of the company brought the acceptance of consumers in the form of slightly higher prices (by 10\% compared to the average), the contingency rate was at lower limit.

The survey results complement and highlight the importance of familiar knowledge of the desired corporate image creation (corporate identity) which is dependent not only on the employees at all positions (from workers up to the management). One negative attribute (customer experience associated with the company) can affect the polarity of the perceived corporate image and thus the willingness to purchase. With the current availability of information in the form of social networks, the publicized cases can have a significant impact on the corporate image. On the basis of our survey, it can be seen that the negative information has a bigger impact on the creation of a negative image which can cause an increase in the cost of communication policy in order to improve the corporate image. Precisely, because of exceed information on public channels and selective perception of information, consumers, there, can even endeavor to reverse the negative consumer responses and their impact on the creation of a negative corporate image. Therefore, it is preferable to actively avoid such situations, to react as soon as possible and be prepared in advance for the process of reaction.

From a managerial perspective, it can be seen how important it is to actively familiarize all employees with the importance of building corporate image not to take it as a mere marketing term introduced in the plans. In particular, employees who are in direct contact with customers (whether in person at the store, as telephone operators or on social networking sites), should be aware not only of the importance of corporate image, but they should be especially impersonated with it. Mediated negative customer experience with the vendor was evaluated as an important factor influencing the corporate image. On the other hand, mediated customer experience with a responsible and reliable procedure was seen as the most important factor in the process of building a positive image.

At the same time, we realize that the creation of the corporate image is a complex process dependent on the number of business modifiable and uncontrollable factors. It is highly subjective and it should also be planned by the marketing department of the company. Companies should be more focused on the acquisition and updating of information about the image from the perspective of consumers.

Finally, moral and ethical dimensions cannot be neglected. If the knowledge of the fact that customers' negative opinions significantly influence the consumer's decision and negative expressions perceived company image, the question arises whether and to what extent it is appropriate to mitigate the presentation of

Vartiak Lukas, Gogolova Martina and Majerova Jana, IBIMA Business Review,

DOI: $10.5171 / 2022.340734$ 
negative reviews by the company. On the basis of our results, there is an option to "overload" the consumer with exclusively positive information which would have an impact on the creation of a positive image and on the customer's decisions as well. On the other hand, the negative expression of fictitious customers can become an instrument of a competitive struggle with the use of corporate communication channels. Such actions, however, are not considered ethical and should not be employed.

Based on the above-mentioned results, our recommendations for Slovak companies are as follows:

1. Companies should focus on building corporate image and on minimizing the negative information presented about them.

2.Companies should address the internal marketing and the presentation of the importance of the corporate image among employees, especially those who are in direct contact with customers. This is due to the fact that negative customer experience with the seller was evaluated as an expression that affects the assessment of a negative corporate image.

\section{Acknowledgment}

The paper was conducted within the project VEGA 1/0064/20: Behaviorism in a socially responsible communication strategy of enterprises.

\section{References}

- Aaker, JL (1997), 'Dimensions of brand personality,' Journal of marketing research, 34 (3), 347356.

- $\quad$ Barich, H. and Kotler, P. (1991), 'A framework for marketing image management,' Sloan management review, 32 (2), 94-104.

- Bartova. H., Barta, V. and Koudelka, J. (2002). Chování spotřebitele a výzkum trhu, Oeconomica, Praha.

- Bielikova, A. (2008), 'Corporate culture - the way of increasing the work quality in transport organization,' Promet - Traffic \& Transportation : scientific journal on traffic and transportation research, 20 (1), 43-45.

- Billett, MT, Jiang Z. and Rego, LL (2014), 'Glamour brands and glamour stocks,' JOURNAL OF ECONOMIC BEHAVIOR \& ORGANIZATION, 107 (SI), 744-759.

- Brown, TJ, Dacin PA, Pratt MG and Whetten David, A. (2006), 'Identity, intended image, construed image, and reputation: An interdisciplinary framework and suggested terminology,' Journal of the Academy of Marketing Science, 34 (2), 99-106.

- Dichter, E. (1985), 'What's in an image,' Journal of consumer marketing, 2 (1), 75-81.

- Dowling, GR (1986), 'Managing your corporate images,' Industrial marketing management, 15 (2), 109-115.

- Dowling, GR (1988), 'Measuring corporate images: A review of alternative approaches,' Journal of Business Research, 17 (1), 27-34.

- Dukerich, J. and Carter, S. (1998), 'Mismached Image: Organizational Responses to conflicts between Identity, Shared External Image and Reputations,' 14th Annual EGOS colloquium. ISBN 0780308166.

- Garcia-Salirrosas EE and Gordillo JM (2021), 'Brand personality as a consistency factor in the pillars of csr management in the new normal,' Journal of Open Innovation: Technology, Market, and Complexity, 7 (2), 134.

- Gardner, BB and LEVY, SJ (1955), The product and the brand. Harvard business review, Cambridge.

- Hampl, M. (2017), 'Beneficiary as a means for a dichotomous representation in political discourse,' Discourse and Interaction, 10 (1), 31-48.

- Hassan S., Shamsudin MF and Mustapha I. (2019), 'The effect of service quality and corporate

Vartiak Lukas, Gogolova Martina and Majerova Jana, IBIMA Business Review, DOI: $10.5171 / 2022.340734$ 
image on student satisfaction and loyalty in TVET higher learning institutes (HLIs),' Journal of Technical Education and Training, 11 (4), 77-85.

- Herbst, D. (2009), Corporate Identity: Aufbau einer einzigartigen

Unternehmensidentität; Leitbild und Unternehmenskultur; Image messen, gestalten und überprüfen.

- Jankalova M. and Vartiak L. (2016), 'Corporate social responsibility issues in the Slovak E-commerce companies,' Scientific Papers of the University of Pardubice, Series D: Faculty of Economics and Administration, 23 (38), 43-55.

- Karaosmanoglu, E. and Elmadağ Bas, AB and Zhang, J. (2011), 'The role of other customer effect in corporate marketing Its impact on corporate image and consumercompany identification,' EUROPEAN JOURNAL OF MARKETING, 4-5 (9-10), 14161445.

- Kaur, H. and Soch, H. (2013), 'Mediating roles of commitment and corporate image in the formation of customer loyalty,' Journal of Indian Business Research, 5 (1), 33-51.

- Kaur, H. and Soch, H. (2018), 'Satisfaction, trust and loyalty: investigating the mediating effects of commitment, switching costs and corporate image,' Journal of Asia Business Studies, 12 (4), 361380.

- Kennedy, SH (1977), 'Nurturing corporate images,' European Journal of Marketing, 11 (3), 119 164.

- Krizanova, A. and Stefanikova, L. (2012), 'Brand influence on customer buying decision in the Slovak Republic,' Practice and research in private and public sector 2012 : international scientific conference : conference proceedings, 105-111. ISBN 9781522516453.
- Kotler, P. and Keller, KL (2007), Marketing management, Grada, Praha.

- Knauth, Langer, SK (1957), Philosophy in a new key, Harvard University Press, Cambridge.

- Lara, JE et al. (2017), 'Institutional image and the role of the managers of a major Brazilian financial institution: Analysis of perceptions of high income customers,' Revista Brasileira de Marketing, 16 (4), 426-438.

- Lehutova, K. and Gregova, E. (2012), 'Impact of economic recession on the consumer behaviour,' Journal on Law, Economy \& Management, 2 (1), 7882.

- Lemming, J., Schuijf, A., and Streukens, S. (2003), 'The role of corporate image and company employment image in explaining application intentions,' JOURNAL OF ECONOMIC PSYCHOLOGY, 24 (1), 1-15.

- Loock M. and Phillips DM (2020), 'A firm's financial reputation vs. Sustainability reputation: Do consumers really care?' Sustainability, 12 (24), 1-17.

- Majerova, J. (2014), 'Analysis of specifics in buying behavior of Slovak customers in Internet environment,' Social Sciences Research (SSR 2014) : proceedings of 2014 2nd international conference, 172-178. ISBN 978-09998551-3-3.

- Mandler, M. (2014), 'Indecisiveness in behavioral welfare economics,' JOURNAL OF ECONOMIC BEHAVIOR \& ORGANIZATION, 97, 219-235.

- $\quad$ Margulies, WP (1977), 'Make most of your corporate identity,' Harvard Business Review, 55, 6674.

- Meffert, H., Burmann, C. and Koers, M. (2005), Markenmanagement, Springer Gabler, Berlin.

- $\quad$ Minkiewicz J., Evans, J., Bridson, K. and Mavondo, F. (2011), 'Corporate image in the leisure

Vartiak Lukas, Gogolova Martina and Majerova Jana, IBIMA Business Review,

DOI: $10.5171 / 2022.340734$ 
services sector,' Journal of services marketing, 25 (2-3), 190-201.

- Nguyen, N. and Leblanc, G. (2001), 'Corporate image and corporate reputation in customers' retention decisions in services,' Journal of retailing and Consumer Services, 8, 227-236.

- Ponisciakova, O. and Kicova, E. (2021), 'Effective use of MBO in the conditions of Slovak companies,' Sustainability, 13 (17), 1-16.

- Rentkova K. and Vartiak L. (2017), 'Emerging Markets excellence: A review of Rajiw Gandhi National Quality Award winners,' Proceedings of the 29th International Business Information Management Association Conference - Education Excellence and Innovation Management through Vision 2020: From Regional Development Sustainability to Global Economic Growth, 705-715. ISBN 978-09860419-7-6.

- Sirgy, MJ and Samli, AC. (1985), 'A path analytic model of store loyalty involving self-concept, store image, geographic loyalty, and socioeconomic status,' Journal of the Academy of Marketing Science, 13 (3), 265-291.
- Thoger, CL. and Askegaard, S. (2001), 'Corporate identity and corporate image revisited-A semiotic perspective,' European Journal of Marketing, 35 (3-4), 292-315.

- $\quad$ Tsai, WC, \& Yang, IW. (2010), 'Does image matter to different job applicants? The influences of corporate image and applicant individual differences on organizational attractiveness,' International Journal of Selection and Assessment, 18 (1), 48-63.

- Vayrakh Yu. V. et al. (2021), 'The model for developing a brand concept for a small construction business,' IOP Conference Series: Earth and Environmental Science, 751 (1), 1-9.

- Vysekalova, J. and Mikes, J. (2009), Image a firemní identita, Grada, Praha. 